\title{
火災時における合成梁の終局曲げ耐力に関する実験的研究 EXPERIMENTAL STUDY ON ULTIMATE FLEXURAL STRENGTH OF COMPOSITE BEAM IN FIRE
}

\author{
安田 聡*, 道越真太郎**, 田川泰久*** \\ Satoshi YASUDA, Shintaro MICHIKOSHI and Yasuhisa TAGAWA
}

\begin{abstract}
The paper is intended to summarize findings from fire resistance tests on simply supported beams conducted as part of a study on the fire resistance of steel-concrete composite beams. The specimens were comprised of H-shaped steel beam and overlying composite slab with profiled steel decks, with studs at the interface. The composite beams were designed to be partial composite. A total of six models were tested. The test parameters included the level of load, cross section of steel beam and presence of fire protection. Based on the test results, a new formulation is proposed to calculate with a good accuracy the flexural strength of composite beam on the basis of the plastic theory taking account of the heat-induced degradation of steel / concrete materials and shear capacity of studs.
\end{abstract}

Keywords : composite beam, fire resistance, ultimate flexural strength, headed stud shear connector, fire resistance test 合成梁，耐火性能，終局曲げ耐力，頭付きスタッド，載荷加熱実験

1. はじめに

鉄骨梁とスラブとを頭付きスタッド（以下，スタッドという）で 結合した合成梁は，スラブの合成効果によって鉄骨梁に比べて正曲 げ耐力が上昇する。このような合成梁の崩壊機構は，鉄骨梁とスラ ブとが一体となって曲げ崩壊する場合とスタッドがせん断破壊して 崩壊する場合とに大別される。一般に, 前者の崩壊機構となる合成 梁を「完全合成梁」といい，後者の崩壊機構となる合成梁を「不完 全合成梁」という。このような合成梁の崩壊機構とそれに対応する 終局曲げ耐力を精度良く評価するにはスラブの合成効果を適切に把 握しなければならない。

合成梁におけるスラブの合成効果は火災時においても期待するこ とができる。中川ら ${ }^{1)}$ は，鉄筋コンクリートスラブおよびデッキプ レートとコンクリートとの合成スラブを用いた合成梁の載荷加熱実 験を行い, 火災時の曲げ耐力にスラブの合成効果が期待できること， 横座屈による不安定な崩壊がスラブの拘束効果により生じにくいこ とを報告している。また，火災時における鉄骨梁および合成梁の崩 壊に至るまでの挙動や崩壊温度の評価法を有限要素解析により検討 している ${ }^{2)}$ 。篗田ら ${ }^{3)}$ は，耐火鋼を用いた合成梁について，火災加 熱を与えた後に漸増載荷する実験を行い，スラブの合成効果を考慮 した火災時の曲げ耐力評価式を提案している。ただし，これらの実 験で確認されたスタッドを用いたスラブの合成効果は常温時に完全
合成梁として設計された梁に限定され，火災時におけるスラブの合 成効果が十分に解明されたとはいえない。

スラブの合成効果はスタッドのせん断耐力に大きく依存する。筆 者らは，スラブ下面から火災加熱を受ける状態を模擬したスタッド の押抜き試験を行い，火災時のスタッドの破壊性状を明らかにする とともに, 破壊形式に対応したスタッドのせん断耐力評価式を提案 している4)。

本研究では，火災時における合成梁のスラブの合成効果を考慮し た終局曲げ耐力および崩壊温度を検討するために，スタッドのせん 断破壊が先行する不完全合成梁を対象に載荷加熱実験を行った。本 報では，塑性設計法に基づいた不完全合成梁の曲げ耐力評価法を考 察するとともに，高温押抜き試験から求めたスタッドのせん断耐力 評価式とあわせて, 火災時に適用した場合の妥当性を検証した。ま た，火災時の合成梁が終局状態に至るまでの挙動について検討を 行った。

\section{2. 実験計画}

\section{1 試験体}

試験体一覧を表 1 に，試験体の形状・寸法を図 1 に示す。試験体 は， H 形断面鉄骨梁とデッキプレート合成床とをスタッドで結合し た，長さ $7500 \mathrm{~mm}$ の実大寸法の合成梁である。試験体数は6体で，主
* 大成建設(侏)技術センター 主任研究員 ·工修

** 大成建設(株)技術センター 主任研究員・博士 (工学)

*** 横浜国立大学大学院工学研究院建築学 教授·工博
Senior Research Engineer, Technology Center, Taisei Corporation, M. Eng.

Senior Research Engineer, Technology Center, Taisei Corporation, Dr. Eng.

Prof., Graduate School of Engineering, Yokohama National University, Dr. Eng. 
な実験パラメータは載荷モーメント, 鉄骨梁の断面寸法および耐火 被覆の有無である。表 1 に示す試験体名の数字は, 鉄骨梁の降伏モー メント ${ }_{s} M_{y}$ に対する載荷モーメントの比を示す。

鉄骨梁は H-400 × $200 \times 8 \times 13 （ \mathrm{SS} 400 ）$ を基本に用い，合成ス ラブ用デッキプレート $(\mathrm{SDP} 2 \mathrm{G}(\mathrm{Z} 12)-75 \times 300 \times 180 \times 120 \times 1.2)$ を連続して梁上に架け渡し, デッキプレートを貫通してスタッドを 梁フランジに溶接した。B-2/3sn はH-588 × $300 \times 12 \times 20(\mathrm{SN} 490 \mathrm{~B})$ を用い, デッキプレートを梁上で断続させて設置し，スタッドを梁 フランジに直接溶接した。試験体には, JIS B 1198 に適合する引張 強さ $400 \mathrm{~N} / \mathrm{mm}^{2}$ 級のスタッドを使用した。なお, B-2/3,B-2/3sn は, 梁両端部の非加熱区間にスタッドを配していない。スラブコンク リートには, 設計強度 $20 \mathrm{~N} / \mathrm{mm}^{2}$ と $30 \mathrm{~N} / \mathrm{mm}^{2}$ の 2 水準の普通コンク リート（以下 $f_{c} 20, f_{c} 30$ という）を用いた。スラブの幅は, 加熱炉 の寸法にあわせて $2960 \mathrm{~mm}$ とした。

各試験体の常温における鉄骨梁とスラブの軸方向耐力を表 2 に示 す。各軸方向耐力は, 日本建築学会「各種合成構造設計指針・同解 説 $\left.^{5)}\right\lrcorner($ 以下, 合成指針という) に従い, 後述する材料試験結果を用 いて算出した。合成指針で計算されるスラブの有効幅 $b_{e}$ は, B- $2 / 3 \mathrm{sn}$ : $2336 \mathrm{~mm}$ ，その他：2288mmである。鉄骨梁 H-400を用いた試験体は, 鉄骨梁の軸方向耐力 ${ }_{s} P_{y}$ よりもスラブの軸方向耐力 ${ }_{c} P_{y}$ が大き い。B-2/3sn は ${ }_{s} P_{y}$ よりも ${ }_{c} P_{y}$ を小さくした試験体で, ${ }_{s} P_{y}$ と ${ }_{c} P_{y}$ の大 小関係の相違が火災時の曲げ耐力に及ぼす影響を検討した。表 2 に は，スタッドによる鉄骨梁とスラブとの合成率 $n_{p} / n_{f}$ をあわせて示し ている。合成率は, 完全合成梁に必要なスタッド本数 $n_{f}$ に対するス タッド配置本数 $n_{p}$ の割合である。言い換えれば, ${ }_{s} P_{y}$ と ${ }_{c} P_{y}$ の最小值 に対するスタッドの総せん断耐力 $\Sigma q$ の割合であり, 完全合成梁の合 成率は 1 となる。本試験体は, 単純支持条件下において, いずれも 合成率が 1 以下の不完全合成梁である。

耐火被覆は, 部材への熱入力を抑制する性能を担うものであり, 部材温度に応じた合成梁固有の曲げ耐力（崩壊温度）に与える影響 はないものと考え ${ }^{6)}$, 本実験では鉄骨梁の耐火被覆を省略した試験 体を基本に用いた。ただし，B-2/3rwのみ，耐火被覆された部材の温 度分布およびその温度分布における曲げ耐力を把握するために，厚
さ $25 \mathrm{~mm}$ の半湿式吹付けロックウールにより耐火被覆を施した。 2.2 使用材料

(1) 鋼材

鉄骨梁およびスタッドの高温引張試験結果を表 3 に示す。鉄骨梁 SS400 材およびスタッドは各々 2 ロットを試験体に用いた。その組 み合わせを表1中に示す。鉄骨梁の試験片はフランジから採取し，ス

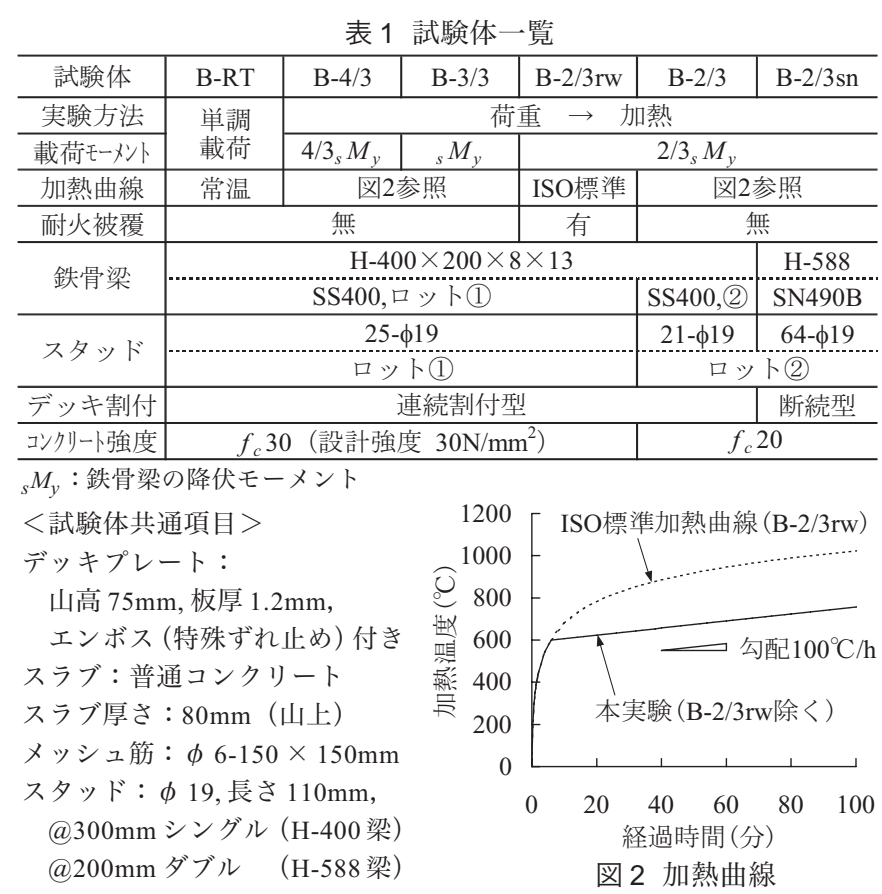

表 2 鉄骨梁とスラブの軸方向耐力および合成率

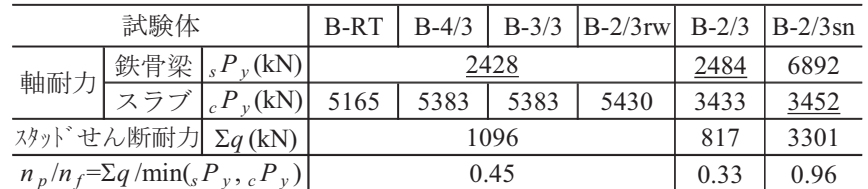

<備考〉下線は, 鉄骨梁とスラブの軸方向耐力のうち小なる方を示す。 ${ }_{s} P_{y}={ }_{s} A{ }_{s} \sigma_{y},{ }_{s} A$ : 鉄骨梁断面積, ${ }_{s} \sigma_{y}$ : 鉄骨梁降伏強度 ${ }_{c} P_{y}=0.85 F_{c} \cdot b_{e} \cdot t_{c}, F_{c}$ : :コリリート強度, $b_{e}$ : スラブ有効幅, $t_{c}$ : スラブ厚さ $n_{p}$ : スタッド配置本数, $n_{f}$ : 完全合成梁に必要なスタッド本数

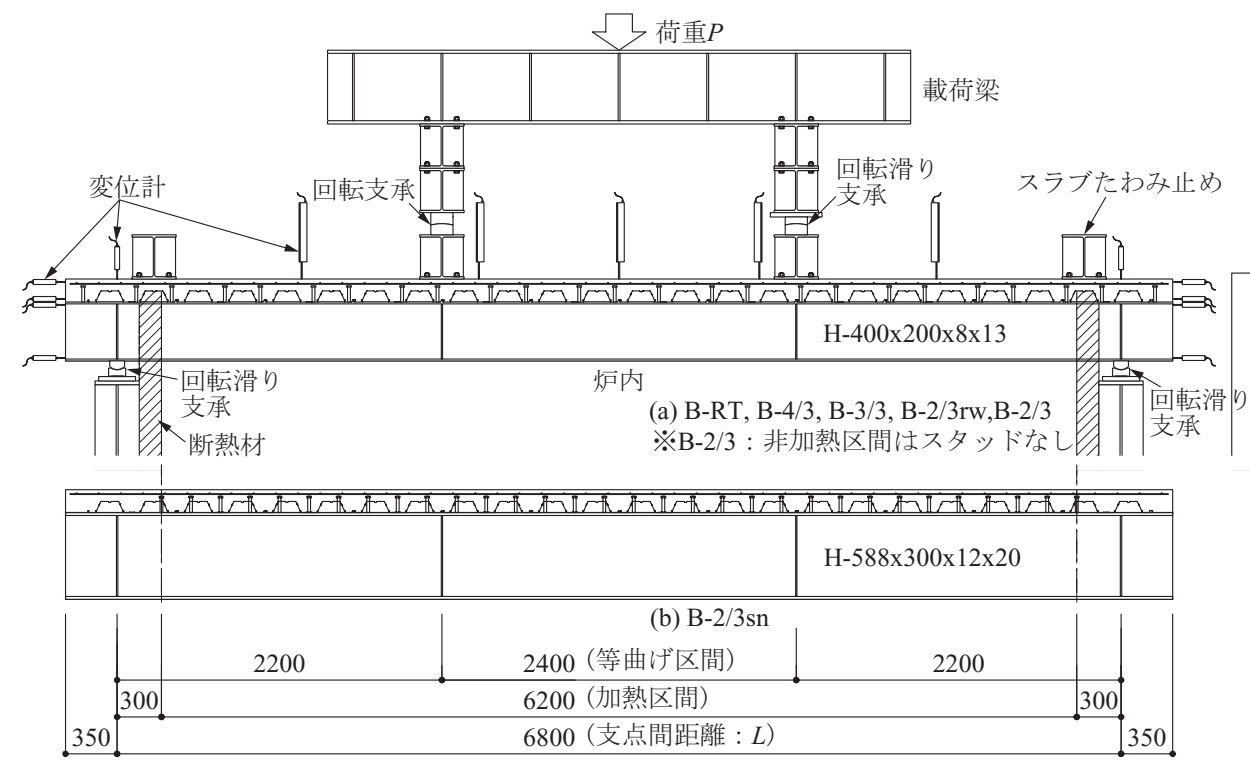

図 1 試験体の形状・寸法および載荷加熱装置

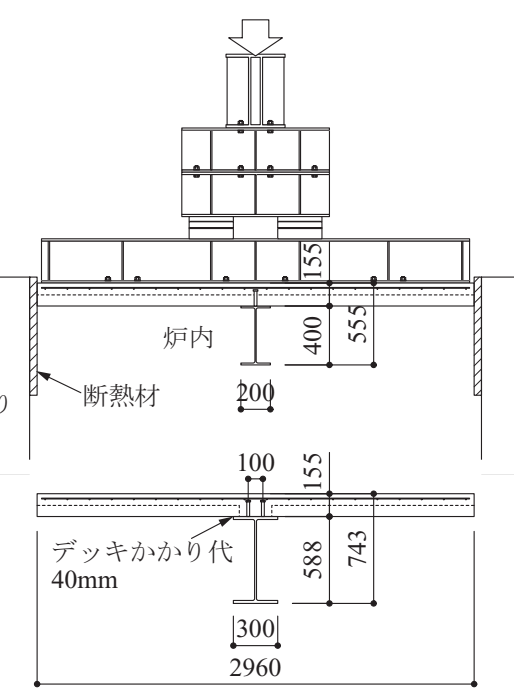

[単位 : $\mathrm{mm}$ ] 
タッドの試験片は径 $19 \mathrm{~mm}$ のタッド製品を切削加工して作成した。 高温引張試験は, 試験片を約 $10^{\circ} \mathrm{C} / \mathrm{min}$ で加熱し, 所定温度に到達し てから約 1 時間その温度を保持した後に単調載荷した。載荷は, 標 点区間におけるひずみ速度が降伏強度時 : $0.3 \% / \mathrm{min}$, 最大強度時： $0.3 \sim 0.5 \% / \mathrm{min}$ となるように，試験機のクロスヘッド速度を制御し た。試験から得られた高温時の鉄骨梁の降伏強度とスタッドの引張 強さを図 4 に示す。

(2) コンクリート

コンクリートの調合を表 4 に, 常温におけるコンクリートの材料 特性を表 5 に示す。試験体に用いたコンクリートと同一調合のコン クリートの高温圧縮試験結果を表 6 に示す。高温圧縮試験に用いた 供試体は，現場封縅養生を行った $\phi 100 \times 200 \mathrm{~mm}$ のシリンダーで, 試 験材齢は3〜4ケ月である。加熱には電気炉を用いた。供試体断面温 度の均一化および変位測定治具の温度平衡を得るために, 供試体表 面が所定温度に到達してから約 2 時間その温度を保持した後に単調 載荷した。 $f_{c} 20$ の応力ーひずみ関係を図 5(a)に示す。表 6 中のヤン グ係数は, 最大応力の $1 / 3$ に相当する応力の割線剛性である。高温 時の圧縮強度残存率（高温時の圧縮強度を常温時の圧縮強度で除し た值）を図 5(b)に示す。

\section{3 載荷加熱方法}

載荷方法は，図 1 に示すように，試験体を単純支持し 2 点載荷に よる等曲げ区間を有する正曲げ載荷とした。B-RTは常温時の曲げ耐 力を把握するために静的に単調載荷した。他の試験体は，鉄骨梁の 降伏モーメント ${ }_{s} M_{y}$ を基準にした曲げモーメントを等曲げ区間に作 用させた状態で試験体下方より加熱した。

加熱曲線を図 2 に示す。耐火被覆を施した B-2/3rw は標準加熱曲 線（ISO834）に準拠して加熱した。他の試験体は $600^{\circ} \mathrm{C}$ まで標準加 熱曲線に準拠し，その後は温度勾配 $100^{\circ} \mathrm{C} /$ 時間で加熱した。本研究 の目的の一つに, 高温時のスタッドのせん断耐力を部材レベルで検 証することがある。そのためには, スタッドをある程度高温にする 必要があった。耐火被覆を省略した試験体を標準加熱曲線に準拠し て加熱した場合, 部材断面内の温度勾配が大きくなり, スタッドの 温度が上昇しないうちに（スタッドの昇温にともなう強度低下がな いうちに), 鉄骨梁の昇温にともなう耐力低下が支配的要因となって

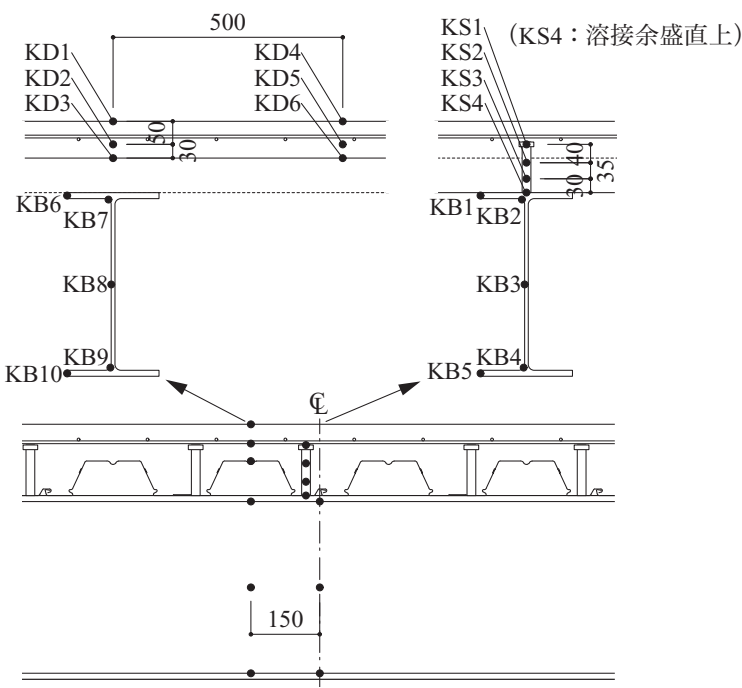

図 3 温度測定位置 [単位 : $\mathrm{mm}$ ]
表 3 鋼材の高温引張試験結果 (a) 鉄骨梁フランジ

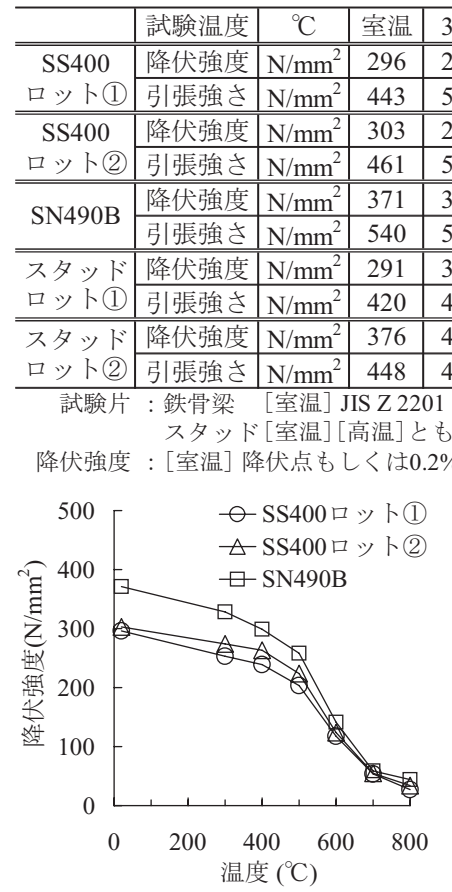

\begin{tabular}{|c|c|c|}
600 & 700 & 800 \\
\hline
\end{tabular}

\begin{tabular}{|l|l|l|l|l|}
239 & 203 & 118 & 54 & 27 \\
\hline
\end{tabular}

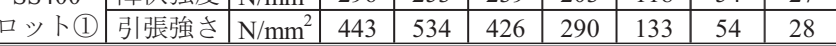

\begin{tabular}{l|ll|l|l|l|l|l|l|l} 
SS400 & 降伏強度 & $\mathrm{N} / \mathrm{mm}^{2}$ & 303 & 274 & 263 & 224 & 124 & 55 & 34 \\
\hline
\end{tabular}

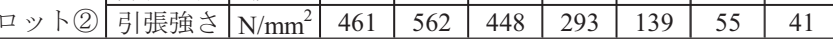

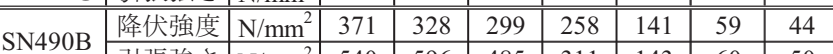

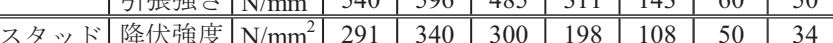

\begin{tabular}{c|c|c|c|c|c|c|c|c|} 
ロット1) 引張強さ & $\mathrm{N} / \mathrm{mm}^{2}$ & 420 & 435 & 341 & 206 & 108 & 51 & 38 \\
\hline
\end{tabular}

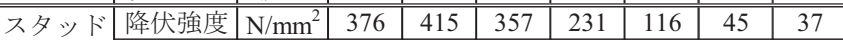

\begin{tabular}{l|l|l|l|l|l|l|l|l|l} 
ロット(2) & 引張強さ & $\mathrm{N} / \mathrm{mm}^{2}$ & 448 & 489 & 381 & 233 & 117 & 49 & 42 \\
\hline
\end{tabular}

室淐] JIS Z 2201 1A号, [高温] JIS G 0567 II-6形

図 4 鋼材の高温引張試験結果

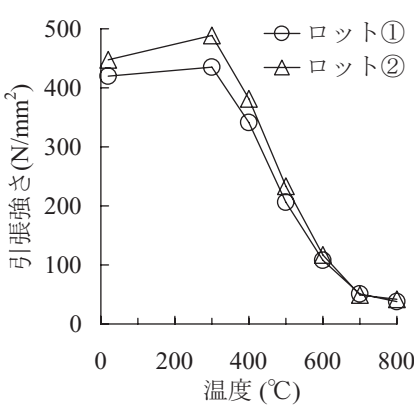

(b) スタッド
表 4 コンクリートの調合

\begin{tabular}{|c|c|c|c|c|c|c|c|c|c|}
\hline \multirow{2}{*}{ 対象 } & \multirow{2}{*}{$\begin{array}{l}\text { W/C } \\
(\%)\end{array}$} & \multicolumn{7}{|c|}{ 単位量 $\left(\mathrm{kg} / \mathrm{m}^{3}\right)$} & \multirow{2}{*}{\begin{tabular}{|c|} 
空気量 \\
$(\%)$
\end{tabular}} \\
\hline & & $\mathrm{W}$ & C & S1 & S2 & G1 & $\mathrm{G} 2$ & $\mathrm{Ad}$ & \\
\hline$f_{c} 20$ & 76.0 & 161 & 212 & 635 & 279 & 689 & 302 & 2.120 & \begin{tabular}{|l|}
4.5 \\
\end{tabular} \\
\hline$f_{c} 30$ & 65.7 & 163 & 248 & 635 & 276 & 665 & 294 & 2.480 & 4.5 \\
\hline
\end{tabular}

セメント C : 普通ポルトランドセメント(密度 $\left.3.16 \mathrm{~g} / \mathrm{cm}^{3}\right)$

細骨材 $\mathrm{S} 1$ : 君津産山砂 (表乾密度 $\left.2.58 \mathrm{~g} / \mathrm{cm}^{3}\right), \mathrm{S} 2$ : 秩父産砕砂 $\left(2.63 \mathrm{~g} / \mathrm{cm}^{3}\right)$

粗骨材 $\mathrm{G} 1$ : 大月産砕石 (表乾密度 $\left.2.62 \mathrm{~g} / \mathrm{cm}^{3}\right), \mathrm{G} 2$ : 秩父産砕石 $\left(2.62 \mathrm{~g} / \mathrm{cm}^{3}\right)$ 混和剂 $\mathrm{Ad}: \mathrm{AE}$ 減水剂標準形種

表 5 コンクリートの材料特性（常温）

\begin{tabular}{c|c|c|c|c|c}
\hline 対象 & $\begin{array}{c}\text { 材齢 } \\
(日)\end{array}$ & $\begin{array}{c}\text { 圧縮強度 } \\
\left(\mathrm{N} / \mathrm{mm}^{2}\right)\end{array}$ & $\begin{array}{c}\text { 割裂強度 } \\
\left(\mathrm{N} / \mathrm{mm}^{2}\right)\end{array}$ & $\begin{array}{c}\text { ヤング係数 } \\
\left(10^{4} \mathrm{~N} / \mathrm{mm}^{2}\right)\end{array}$ & ポアソン比 \\
\hline $\mathrm{B}-\mathrm{RT}$ & 202 & 33.2 & 2.54 & 3.01 & 0.23 \\
\hline $\mathrm{B}-2 / 3 \mathrm{rw}$ & 209 & 34.9 & 2.69 & 2.71 & 0.21 \\
\hline $\mathrm{B}-4 / 3, \mathrm{~B}-3 / 3$ & 212 & 34.6 & 2.76 & 2.88 & 0.23 \\
\hline $\mathrm{B}-2 / 3$ & 110 & 22.1 & 1.97 & 2.56 & 0.19 \\
\hline $\mathrm{B}-2 / 3 \mathrm{sn}$ & 104 & 21.7 & 1.67 & 2.44 & 0.19 \\
\hline \\
シリンダー $\phi 100 \mathrm{~mm} \times 200 \mathrm{~mm}$ の3本の平均 (現場封縅養生)
\end{tabular}

表 6 コンクリートの高温圧縮試験結果

\begin{tabular}{c|c|c|c|c|c|c|c|c}
\hline & 試験温度 & ${ }^{\circ} \mathrm{C}$ & 室温 & 200 & 300 & 400 & 600 & 800 \\
\hline \multirow{2}{*}{$f_{c} 20$} & 圧縮強度 & $\mathrm{N} / \mathrm{mm}^{2}$ & 23.0 & 17.2 & 20.3 & 17.6 & 10.3 & 5.8 \\
\cline { 2 - 9 } & やリ゙係数 & $10^{4} \mathrm{~N} / \mathrm{mm}^{2}$ & 2.59 & 1.81 & 1.65 & 1.14 & 0.55 & 0.37 \\
\hline$f_{c} 30$ & 圧縮強度 & $\mathrm{N} / \mathrm{mm}^{2}$ & 26.6 & 24.9 & - & 22.5 & 15.1 & 7.5 \\
\hline
\end{tabular}

供試体：シリンダー $\phi 100 \mathrm{~mm} \times 200 \mathrm{~mm} （$ 現場封緘養生）

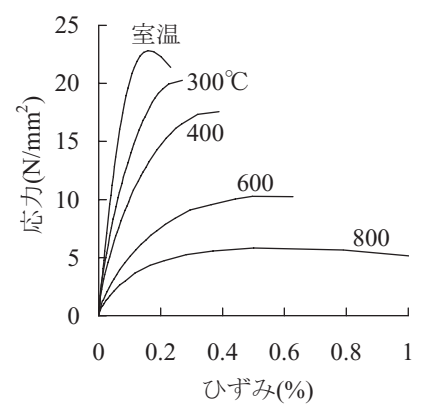

(a) 応力ーひずみ関係 $\left(f_{c} 20\right)$

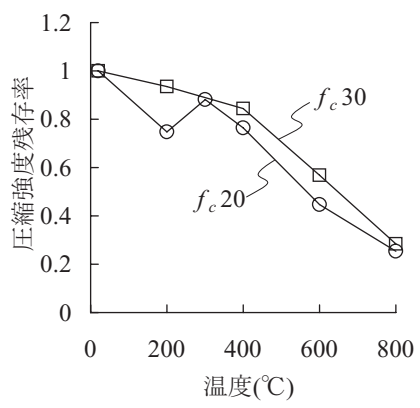

(b) 圧縮強度残存率
図 5 コンクリートの高温圧縮試験結果 
崩壊に至ることが予想されたため, 本実験では, $600^{\circ} \mathrm{C}$ 以降の温度上 昇を小さくした加熱曲線を基本に用いることとした。

\section{4 変位および温度測定方法}

試験体の変形は, 図 1 に示すように, スラブ上面の鉛直変位およ び部材端部の水平変位（スラブと鉄骨梁の相対変位を含む）を測定 した。試験体各部の温度測定位置を図 3 に示す。試験体温度は, ス パン中央の鉄骨梁 10 点, スタッド 4 点およびスラブ (山上) コンク リート 6 点について $\phi 0.65 \mathrm{~mm}-\mathrm{K}$ 型熱電対を設置して測定した。

\section{3. 実験結果}

\section{1 常温単調載荷実験}

B-RT の荷重とたわみの関係を図 6 に示す。荷重は図 1 に示す試験 機荷重 $P$ を, たわみはスパン中央の鉛直変位を表す。図中に示す弾 性剛性計算值 ${ }_{C} K$ および降伏モーメント計算値 ${ }_{c} M_{y}$ は合成指針に従い 求めた。 ${ }^{M} M_{u 1}$ は後述する曲げ耐力計算值である。初期剛性は計算值 ${ }_{c} K$ と良く一致している。 ${ }_{c} M_{y}$ を超えると剛性は明膫に低下し, たわ み $\delta=286 \mathrm{~mm}$ で最大耐力を示した。最大耐力時には部材端部の鉄骨 梁とスラブに約 $20 \mathrm{~mm}$ のずれが生じていた。

B-RT の最終破壊状況を写真 1 に示す。実験終了後に, 載荷点近傍 における上フランジの局部座屈と支点直上におけるスタッド 1 本の

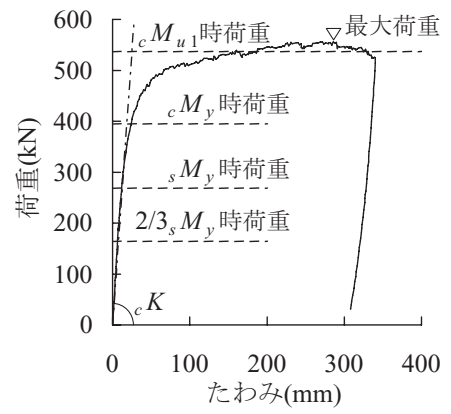

図 6 荷重一たわみ関係（B-RT）

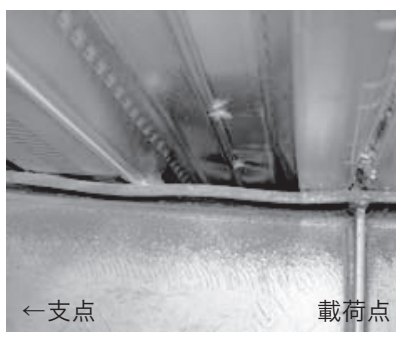

写真 1 上フランジの局部座屈 (B-RT)

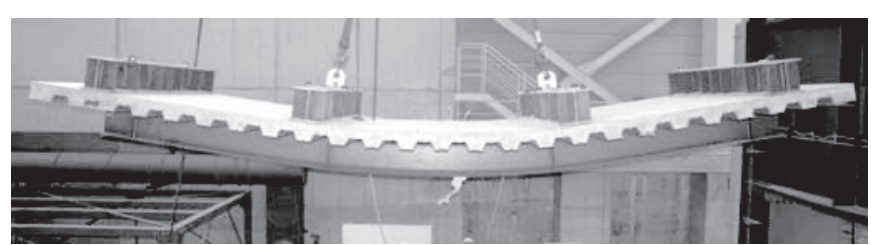

(a) $B-4 / 3$

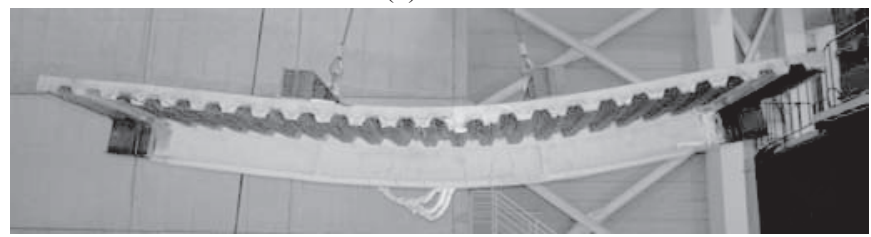

(b) B-2/3rw

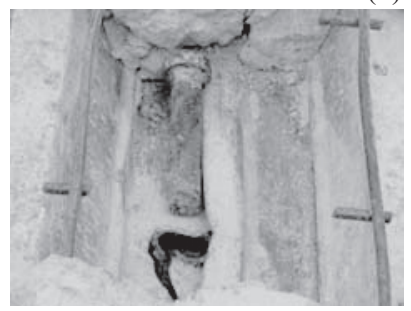

(c) スタッドの破断（B-2/3）

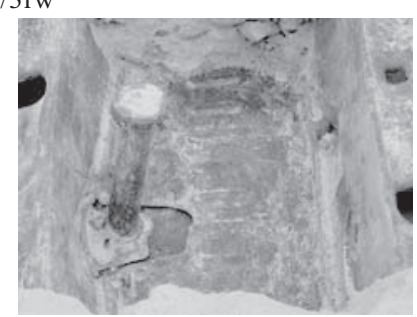

(d) スタッドの変形 (B-4/3) 写真 2 最終破壊状況
破断が確認された。なお，鉄骨梁の横座屈やスラブコンクリートの 圧壊は観察されなかった。

\section{2 載荷加熱実験}

載荷加熱した試験体のたわみと下フランジ温度の関係を図 7 に, たわみ速度と経過時間の関係を図 8 に示す。いずれの試験体も，た わみ $\delta$ が $340 \mathrm{~mm}(\delta / L=1 / 20, L$ : 支点間距離）を超え，たわみ速度 が急速に増大し，僅かではあるが荷重が低下したため, 終局状態に 至ったものと判断し実験を終了した。以後，本実験における試験体 の崩壊温度（崩壊時の部材温度）には実験終了時の温度を用いる。

(1) 破壊状況

載荷加熱した試験体の最終破壊状況を写真 2 に示す。載荷加熱し た試験体には, B-RTに見られた上フランジの局部座屈は観察されな かった。B-4/3,B-3/3,B-2/3sn において，等曲げ区間のスラブ上面に コンクリートの圧壊が観察された。B-2/3rwは, 耐火被覆の剥離・剥 落はなかったが，梁下端の耐火被覆（ロックウール）に多数の亀裂 が生じているのが確認された。B-2/3 は, 梁片側半分のスタッド 12 本が根元から破断しているのが確認された。スタッドの破断状況を 写真2(c)に示す。スタッド軸部の変形は小さく, また変形は根元に 集中しており, 文献4)で報告した高温押抜き試験におけるス夕ッド の破断状況と同様の様相を示した。その他の破壊相として, 写真2(d)
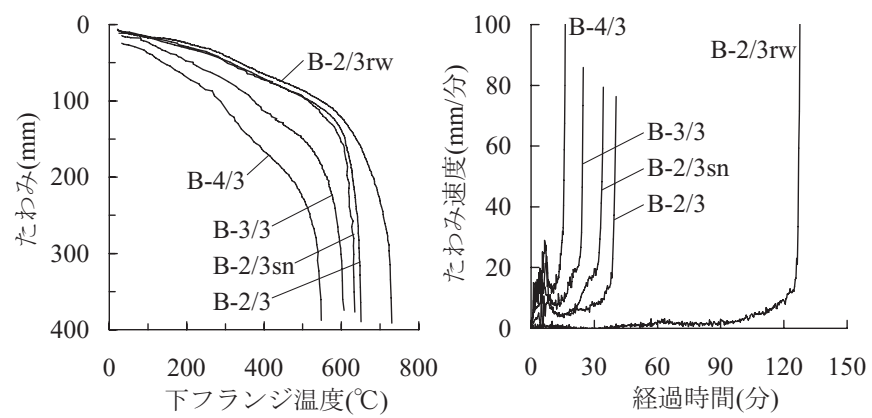

図 7 たわみ一温度関係

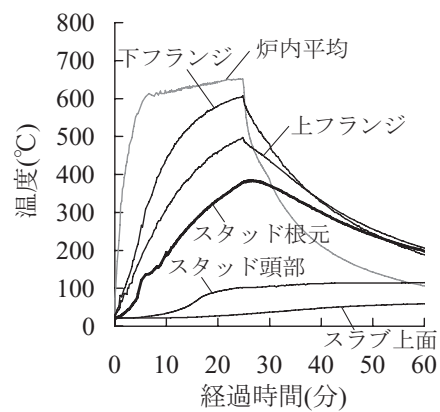

(a) B-3/3

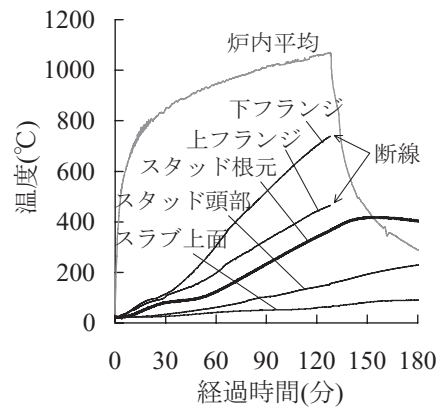

(c) B-2/3rw

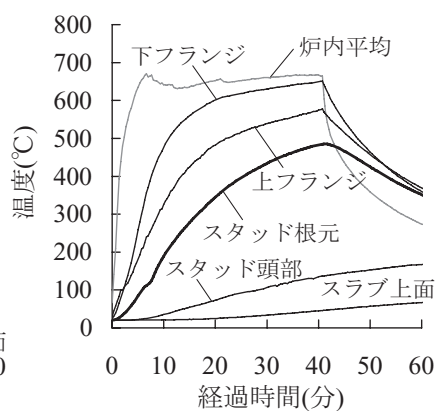

(b) B- $2 / 3$

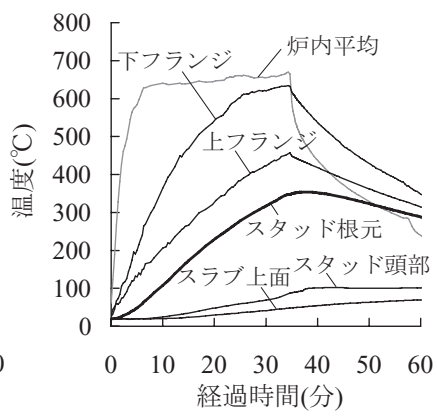

(d) B-2/3sn
図 9 各部の温度履歴 

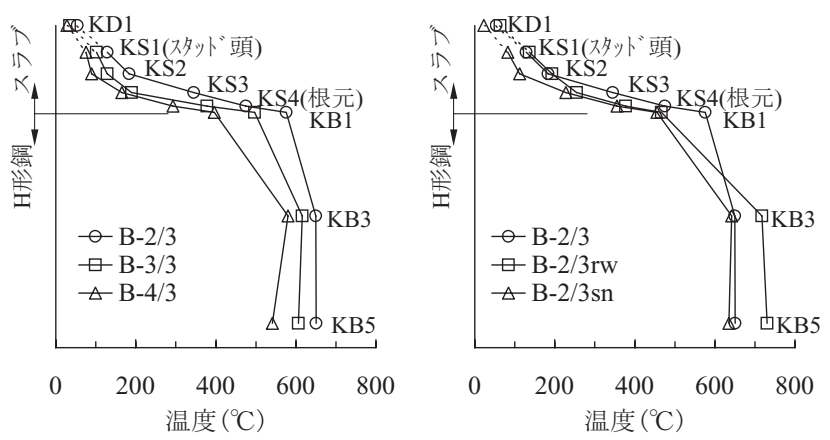

図 10 崩壊時の部材断面内温度分布

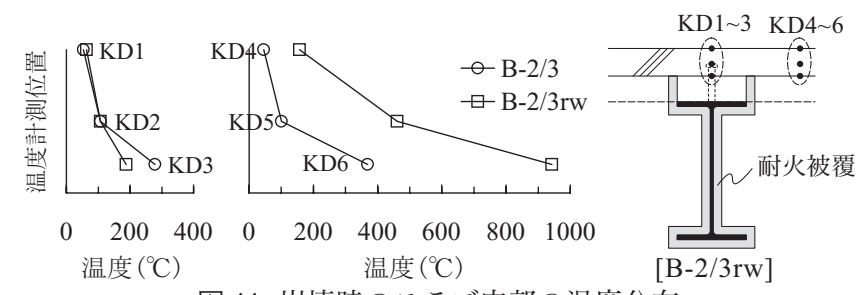

図 11 崩壊時のスラブ内部の温度分布

に示すような,デッキプレートみぞ側面の変形やデッキプレートの ちぎれ破断が観察された。

(2) 温度分布

試験体各部の温度履歴を図 9 に, 崩壊時の断面内温度分布を図 10 に示す。本実験ではスラブ下面側から加熱を与えたため，部材温度 は断面内で温度勾配があり一様ではない。特にスラブ断面内（ス タッド）の温度勾配が大きい。耐火被覆した B-2/3rwは, 他の試験 体に比べて崩壊時の下フランジと上フランジ（スタッド根元）の温 度差が大きくなっている。

B-2/3 と B-2/3rwの崩壊時のスラブ内温度分布を図 11 に示す。 B- $2 / 3$ のKD1 3 と KD4 6の温度分布は同程度であった。B-2/3rw は, 図 11 に示すように，上フランジとデッキプレートとの空間を塞ぐように 耐火被覆を施しており，鉄骨梁直上のスラブは直接加熱されていな いため, KD1 3 と KD4 6 の温度分布は異なっている。

\section{3 梁の軸方向変形}

B-4/3 と B-2/3 の梁の軸方向変形と鉄骨梁温度の関係を図 12 に示 す。軸方向変形は, 図 16 に示す部材両端部の同一高さ位置における 水平変位計測值の和である。そのため, 軸方向変形には昇温にとも なう伸び出し変形のほかに, 端部の回転成分と部材がたわむことに よる縮み成分が含まれている。鉄骨梁温度は, 図3に示す KB1 10の 計測值の平均である。両試験体とも, 昇温にともない鉄骨梁下部の 伸び変形が増大している。スラブ下部と鉄骨梁上部の加熱初期の軸 方向変形は伸び変形であったが, 崩壊時には縮み変形に転じている。

鉄骨梁の伸び出し量と鉄骨梁温度の関係を図13に示す。鉄骨梁の 伸び出し量は, 厳密には中立軸位置で評価するべきであるが, ここ では鉄骨梁上部と鉄骨梁下部の軸方向変形の平均を用いた。図には, この平均值を加熱区間長さ $(6200 \mathrm{~mm})$ で除し，ひずみに換算した 值を示す。鉄骨梁の伸び出し量は鉄骨梁温度に比例して増加し，鋼 種，断面寸法，合成率に関わらず，その増加量は鋼材の線膨張係数 $\left(12 \times 10^{-6} /{ }^{\circ} \mathrm{C}\right)$ とほぼ同じであった。このことは, 西垣ら ${ }^{7)}$ が行っ た合成梁の載荷加熱実験結果と一致する。これより，スラブが鉄骨 梁の伸び出しを拘束する効果は小さいといえる。

鉄骨梁の伸び出し量とたわみの関係を図 14 に示す。図 13 と図 14

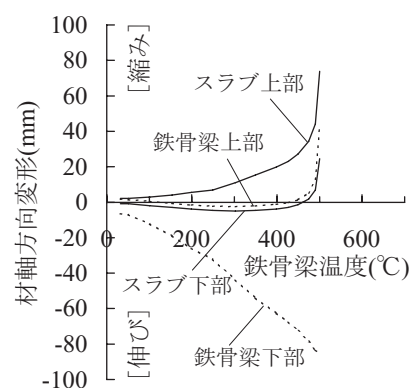

(a) B-4/3

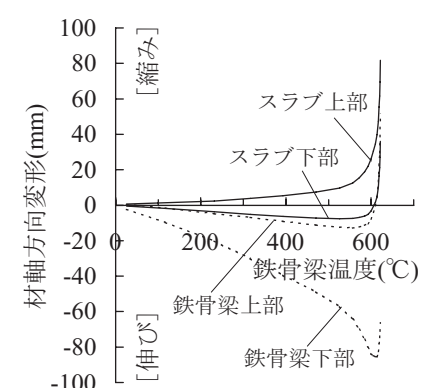

(b) $\mathrm{B}-2 / 3$
図 12 軸方向変形一温度関係

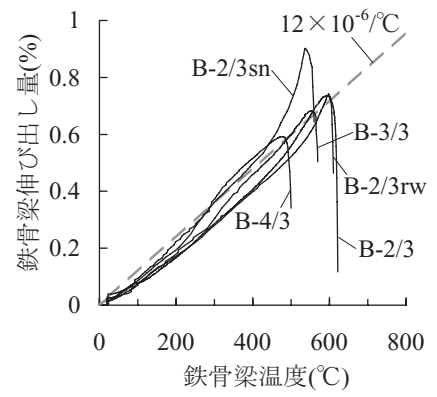

図 13 伸び出し量－温度関係

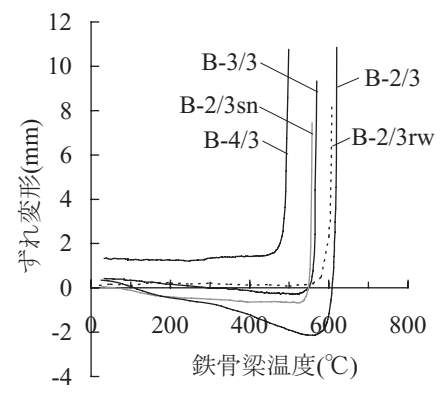

図 15 鉄骨梁とスラブのずれ変形

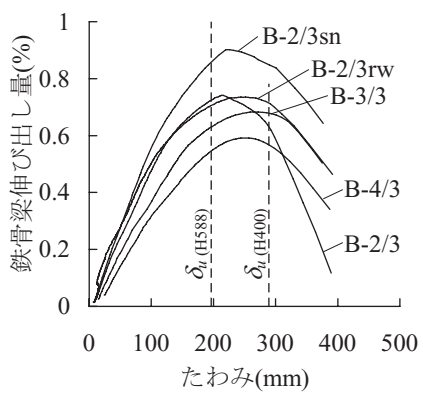

図 14 伸び出し量一たわみ関係

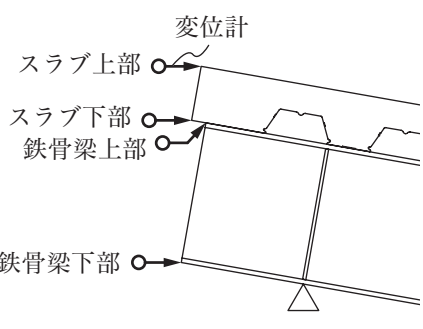

図 16 梁の軸方向変形
に示すように，鉄骨梁の伸び出し量は，崩壊温度に近づくとそれま での伸びる方向から縮む方向に反転し, 崩壊時には部材のたわみに よる縮み成分が卓越する様子がわかる。図 14 には, 参考として下記 に示すISO834 で規定される限界たわみ $\delta_{u}$ を破線で示す。

$$
\delta_{u}=L^{2} /(400 \cdot d)
$$

ここで, $L$ : 支点間距離 $(6800 \mathrm{~mm}), d$ : 鉄骨梁せい $(400,588 \mathrm{~mm})$ 3.4 鉄骨梁とスラブのずれ変形

スラブ下部と鉄骨梁上部の軸方向変形の差（以下，ずれ変形とい う）と鉄骨梁温度の関係を図 15 に示す。ずれ変形は，鉄骨梁とスラ ブが図16のようにずれる方向を正值とした。正曲げモーメントに対 しては正方向のずれ変形が, 鉄骨梁の温度による伸び出しに対して は負方向のずれ変形が生じる。いずれの試験体も, 崩壊時には正方 向のずれ変形が増大しており, 正曲げモーメントに対するスタッド のせん断抵抗が低下して崩壊に至ったものと考えられる。

スラブが鉄骨梁の伸び出しを拘束する効果は小さいことは既に述 べた。B-2/3,B-2/3sn は, 加熱当初, 負方向のずれ変形が増加してお り，鉄骨梁の伸び出しがずれ変形として現れている。スラブに作用 する軸方向力は鉄骨梁からスタッドを介して伝達されるため, 鉄骨 梁の伸び出しにより負方向のずれ変形が生じている場合のスラブに 圧縮力は作用しない。圧縮力が作用していないスラブは正曲げに対 
して寄与しておらず，鉄骨梁のみで作用モーメントを負担している ことになる。終局時には, 昇温にともなう材料強度の低下により, 鉄 骨梁のみで作用モーメントを負担できなくなり，スラブが正曲げに 寄与するようにたわみ（曲率）が増大して正方向のずれ変形に転じ たものと考えられる。一方, B-4/3 は, 鉄骨梁の全塑性モーメントよ りも大きな曲げモーメントが作用しているため, 常にずれ変形はス ラブが曲げに寄与する（スラブに圧縮力が作用する）正方向を維持 している。B-2/3rwのずれ変形の変化は小さいが, これは耐火被覆さ れた鉄骨梁と同程度の温度までスラブの平均温度(KD4 6)が上昇し ており，スラブ自身も加熱により伸び出していることが要因として 考えられる。このように, 崩壊に至るまでのずれ変形は, 作用モー メントや部材への熱入力の差異によって異なった経路を辿ることが わかる。なお，鉄骨梁とスラブのずれ変形が正方向に増大し始める 時期は, 図 13 に示す鉄骨梁の伸び出し量が伸びる方向から縮む方向 に反転する（たわみによる縮み成分が卓越する）時期とほぼ等しい。

\section{4. 火災時における合成梁の曲げ耐力}

\section{1 不完全合成梁の耐力評価モデル}

一般に，完全合成梁の曲げ耐力は，合成断面の全塑性モーメント を用いて算定されている ${ }^{5), 8)}$ 。不完全合成梁の曲げ耐力も，完全合 成梁と同様の方法で算定することができるものと考えられる。以下 では，塑性設計法に基づいた不完全合成梁の耐力評価に用いる応力 状態について検討する。なお，スラブに作用する圧縮力は鉄骨梁か らスタッドを介して伝達され，スラブの有効幅内には一様な圧縮応 力が作用するものと仮定する。

合成梁の終局時の応力状態模式図を図 17 に示す。鉄骨梁単体の応 力状態を $\mathrm{A}$, 不完全合成梁の応力状態を $\mathrm{B}$, 完全合成梁の応力状態 を C として示す。各応力状態から求まる合成梁の曲げ耐力と合成率 $n_{p} / n_{f}$ の関係を図 18 に示す。曲げ耐力は, 仮定した応力状態の任意点 まわりのモーメントを合計して求められる。合成率が 1 以上の場合 は完全合成梁となり，合成指針では $\mathrm{C}_{2}$ および $\mathrm{C}_{3}$ の応力状態を仮定 して曲げ耐力を算定している。いずれもスラブの応力状態は，コン クリート強度 $F_{c}$ を 0.85 倍したストレスブロックに置換している。

合成率が 1 未満の不完全合成梁では, スラブに作用する圧縮力 $C$ はスタッドのせん断耐力 $\Sigma q$ に依存する。合成率が増すと, 断面全体 の圧縮合力と引張合力の大きさが等しくなるように，塑性中立軸は 鉄骨梁中心から上方に移動するが，塑性中立軸は鉄骨梁断面内に留 まる。この場合のスラブの応力状態は以下の 2 系統の仮定が考えら れる。一つは，塑性中立軸が鉄骨梁断面内にあるので，スラブ全面 に圧縮力が作用するとした仮定 $\mathrm{B}_{1}$ である ${ }^{8)}$ 。コンクリートの圧縮応
力は $C=\Sigma q$ となる值 $f_{c}, \quad\left(f_{c}{ }^{\prime}<0.85 F_{c}\right)$ をとる。もう一つは, コンクリー 卜の終局状態を想定した圧縮応力 $0.85 F_{c}$ が $C=\Sigma q$ となるスラブ厚さ の範囲に作用するとした仮定 $\mathrm{B}_{2}$ である ${ }^{9)}$ 。ただし， $\mathrm{B}_{2}$ の塑性中立軸 は見かけ上 $2 つ$ 存在することになる。

次に $\mathrm{B}_{1}$ と $\mathrm{B}_{2}$ の仮定のもと, 合成率が 1 以上の完全合成梁の応力 状態を再考する。鉄骨梁の軸方向耐力 ${ }_{s} P_{y}$ よりもスラブの軸方向耐 力 ${ }_{c} P_{y}$ が大きい場合 $\left({ }_{s} P_{y}<{ }_{c} P_{y}\right), \mathrm{B}_{1}$ の仮定では合成率が 1 以上にな ると $\mathrm{C}_{1}$ の応力状態に移行する。塑性中立軸は上フランジ上面に位置 し，コンクリートの圧縮応力 $f_{c}{ }^{\prime}$ は $0.85 F_{c}$ 以下となり, 合成指針で仮 定している $\mathrm{C}_{2}$ の応力状態には移行しない。一方， $\mathrm{B}_{2}$ の仮定では，合 成率が 1 以上になると, $C={ }_{s} P_{y}$ となるスラブ厚さの範囲に $0.85 F_{c}$ の コンクリート応力が作用する $\mathrm{C}_{2}$ の応力状態に移行する。なお, ${ }_{s} P_{y}>{ }_{c} P_{y}$ の場合は, $\mathrm{B}_{1}$ と $\mathrm{B}_{2}$ とも合成率が 1 以上になると $\mathrm{C}_{3}$ の応力状 態に移行する。

不完全合成梁の曲げ耐力は $\mathrm{B}_{1}$ の応力状態を, 完全合成梁の曲げ耐 力は $\mathrm{C}_{2}$ の応力状態を仮定して算定する方法が受け入れやすいが，そ の場合の曲げ耐力は合成率 1 を境に不連続となる。仮定した 2 系統 の応力状態は, 中立軸の矛盾や応力状態の連続性に欠けるなどの問 題があるが, $\mathrm{A} \rightarrow \mathrm{B}_{1} \rightarrow \mathrm{C}_{1}$ は合成梁の曲げ耐力の下界を, $\mathrm{A} \rightarrow \mathrm{B}_{2} \rightarrow$ $\mathrm{C}_{2}$ は合成梁の曲げ耐力の上界を示すものと考えられる。以下， $\mathrm{A} \rightarrow$

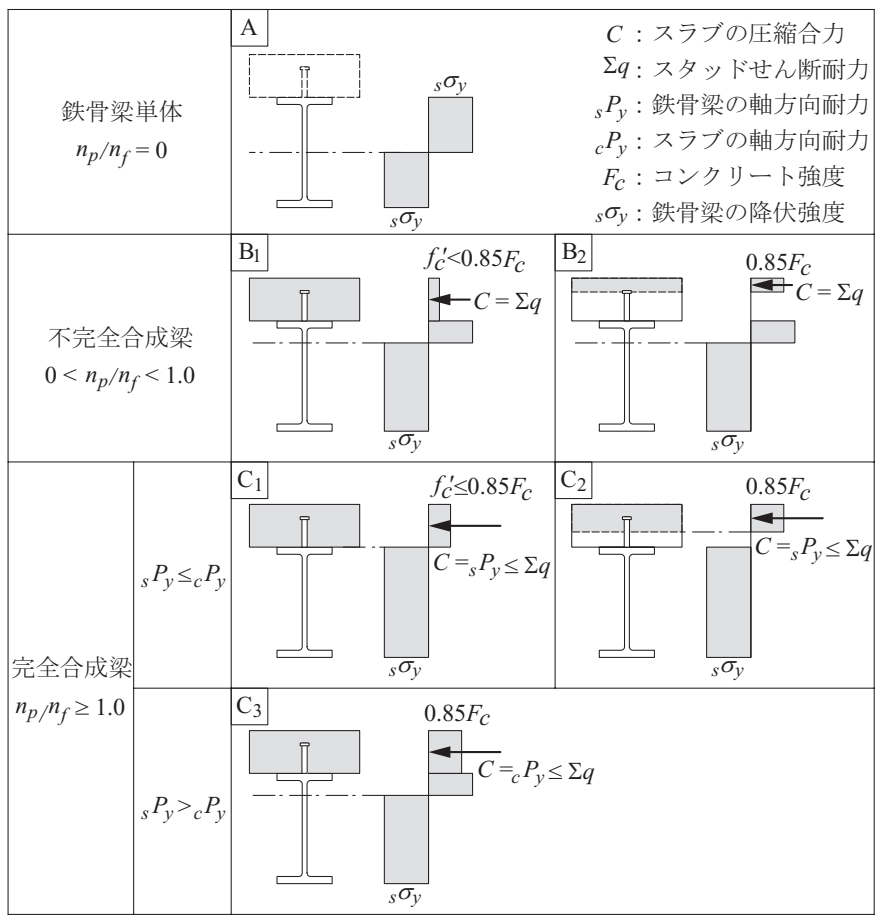

図 17 応力状態模式図

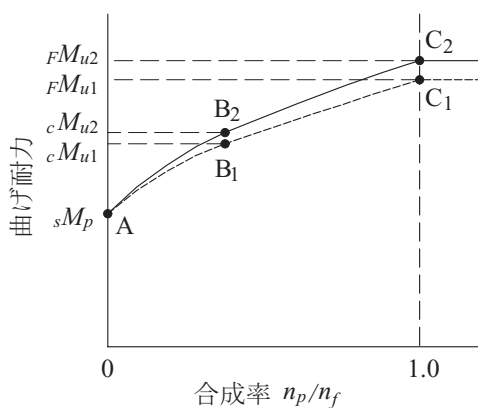

図 18 曲げ耐力ー合成率関係

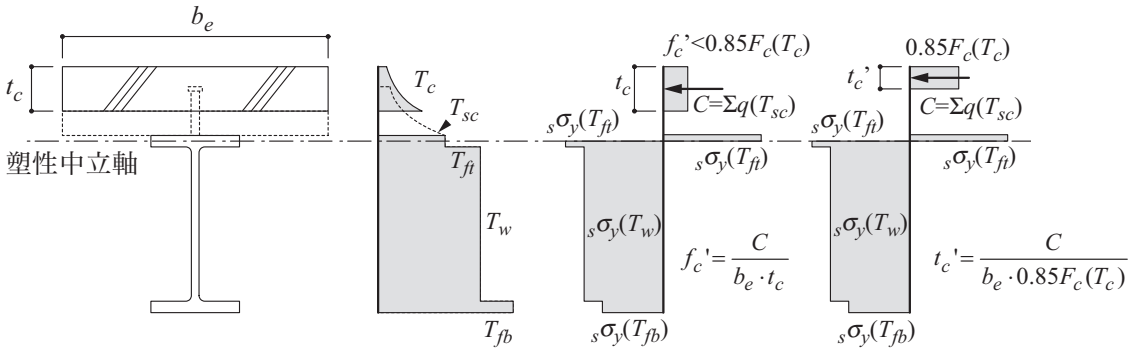

[断面図]
[温度分布］［評価モデル 1］

図 19 耐力評価モデル (不完全合成梁) 
$\mathrm{B}_{1} \rightarrow \mathrm{C}_{1}\left(\mathrm{C}_{3}\right)$ を評価モデル $1, \mathrm{~A} \rightarrow \mathrm{B}_{2} \rightarrow \mathrm{C}_{2}\left(\mathrm{C}_{3}\right)$ を評価モデル 2 とし, この $2 つ の$ 評価モデルに基づいて, 火災時における合成梁の曲げ耐 力の評価を試みる。

\section{2 火災時における合成梁の曲げ耐力の評価}

各試験体の加熱時の曲げ耐力と下フランジ温度の関係を図20に示 す。図中の○印は各試験体の崩壊温度実験值である。合成梁の加熱 時の曲げ耐力は, 図 19 に示すように部材断面をスラブ, スタッド, 上フランジ, ウェブ, 下フランジの 5 つの要素に分けて, 各要素ご とに実験時に測定された温度に対応する材料強度を用い，仮定した 応力状態の任意点まわりのモーメントを合計して求めた。スラブの コンクリート強度は, 図3に示す KD4 6の平均温度 $T_{c}$ に対応する圧 縮強度(常温強度に高温圧縮試験による圧縮強度残存率を乗じた值) を用い, 鉄骨梁各部の鋼材強度は有効降伏強度（高温引張試験にお けるひずみ $1 \%$ 時応力）を用いた。スタッドのせん断耐力は, 文献 4)で提案している評価式により算定した。高温時のスタッドのせん 断耐力は, 図 21 に示すように, 評価温度としてスタッド根元の温度 $T_{s c}$ を用い, コンクリートの局部破壊で決定される耐力 $q_{c}$ とスタッ ドの破断で決定される耐力 $q_{s}$ の小なる值（図中の太線）として求め られる。なお, 非加熱区間に配したスタッドについては常温時のせ ん断耐力を用いた。図 20 には, 評価モデル 1 および評価モデル 2 に
よる曲げ耐力計算值 ${ }_{c} M_{u 1},{ }_{c} M_{u 2}$ の他に, 完全合成梁とした場合の評 価モデル 2 にる曲げ耐力 ${ }_{F} M_{u 2}$ と鉄骨梁の全塑性モーメント ${ }_{s} M_{p}$ を あわせて示している。各曲げ耐力は，常温における鉄骨梁の全塑性 モーメント ${ }_{s} \bar{M}_{p}$ で除して無次元化している。

本実験のような単純梁の場合には, スパン中央の正曲げモーメン トが一定であるため, 合成梁部材の曲げ耐力がこの值まで低下した ときに崩壊に至る。各試験体の崩壊温度（崩壊時の部材温度）を用 いた曲げ耐力計算値と実験值を比較して表 7 に示す。 ${ }^{M} M_{u 2}$ の実験值

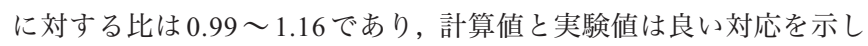
ている。B-2/3sn を除き, ${ }_{c} M_{u 1}$ は ${ }_{c} M_{u 2}$ に比べて 1 割程度低く, ${ }_{c} M_{u 1}$ は実験值を若干過小に評価している。B-2/3sn は, 後述するょうに, 崩壊時の鉄骨梁とスラブの軸方向耐力がほぼ等しくなったため, ${ }_{c} M_{u 1}$ と ${ }_{c} M_{u 2}$ はほぼ同じ值となった。

図 21 には, 曲げ耐力実験值と ${ }_{c} M_{u 2}$ を比較することにより同定し たスタッドのせん断耐力を○印で示している。B-3/3 と B-2/3rwは, 曲げ耐力実験值が完全合成梁とした耐力計算值 ${ }_{F} M_{u 2}$ を超えているた めスタッドのせん断耐力を同定できないが, 参考として合成率が 1 となる時のスタッドのせん断耐力を $\triangle$ 印で示す。文献 4)によるス タッドの耐力評価式は，合成梁の曲げ実験から同定したスタッドの せん断耐力と良い対応を示しているのがわかる。

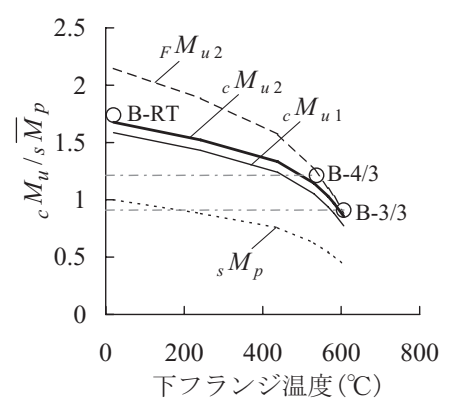

(a) B-RT, B- $4 / 3, \mathrm{~B}-3 / 3$

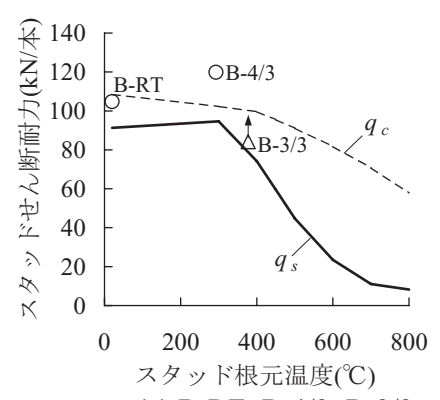

(a) B-RT, B- $4 / 3, \mathrm{~B}-3 / 3$

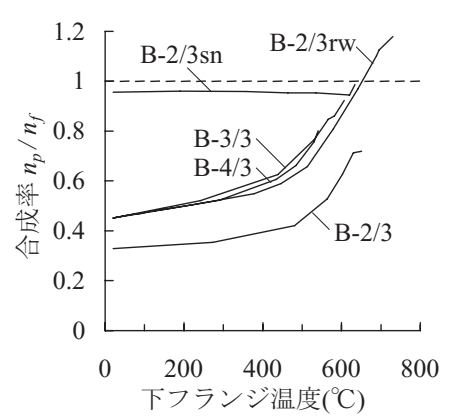

図 22 合成率の推移

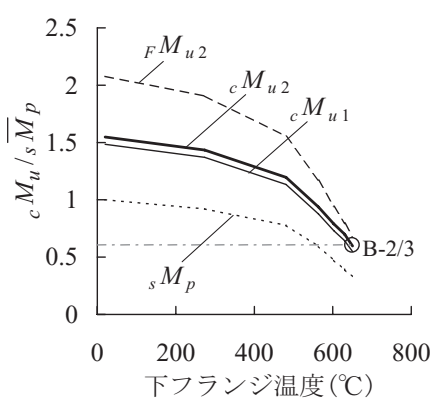

(b) $\mathrm{B}-2 / 3$

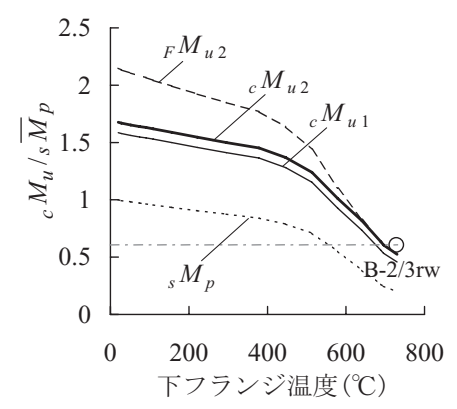

(c) B-2/3rw

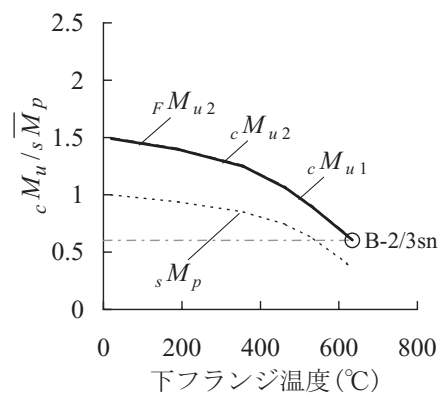

(d) $\mathrm{B}-2 / 3 \mathrm{sn}$

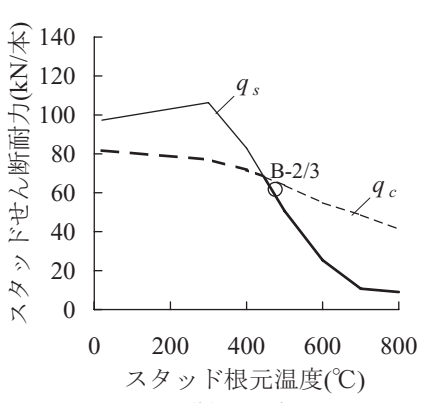

(b) B-2/3

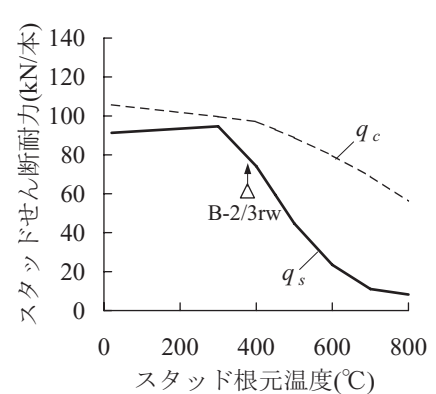

(c) $\mathrm{B}-2 / 3 \mathrm{rw}$

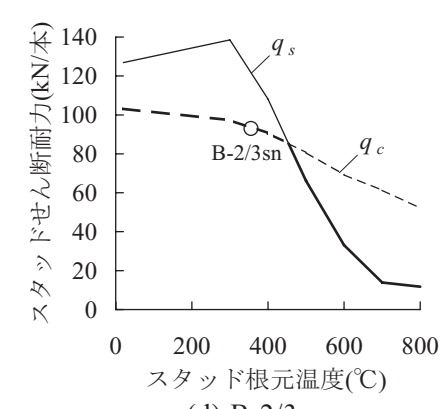

(d) $\mathrm{B}-2 / 3 \mathrm{sn}$

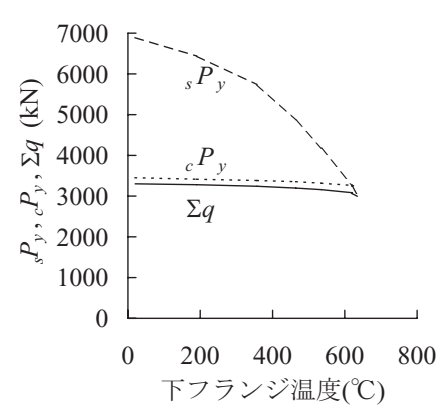

(c) $\mathrm{B}-2 / 3 \mathrm{sn}$

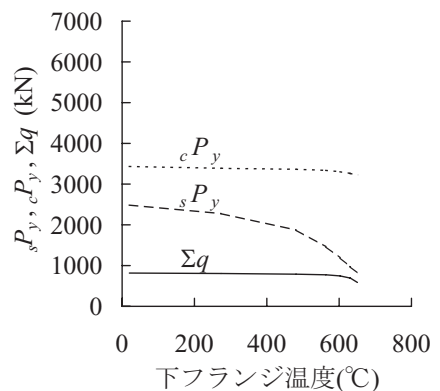

(a) B- $2 / 3$

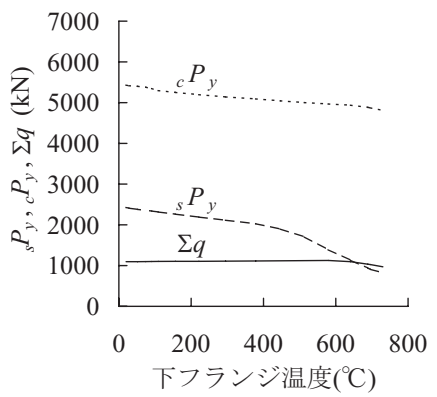

(b) B-2/3rw

図 23 鉄骨梁とスラブの軸方向耐力およびスタッドせん断耐力 
表 7 崩壊時の曲げ耐力実験值と計算值の比較

\begin{tabular}{|c|c|c|c|c|c|c|c|}
\hline & 試験体 & B-RT & B-4/3 & B-3/3 & B-2/3rw & B- $2 / 3$ & B- $2 / 3 \mathrm{sn}$ \\
\hline & $e_{e} M_{u}$ & 662 & 462 & 347 & 231 & 236 & 962 \\
\hline & ${ }_{c} M_{u 1}$ & 604 & 386 & 295 & 174 & 214 & 959 \\
\hline & $M_{u} /{ }_{c} M_{u 1}$ & 1.10 & 1.20 & 1.18 & 1.33 & 1.11 & 1.00 \\
\hline & ${ }_{c} M_{u 2}$ & 639 & 421 & 327 & 200 & 233 & 968 \\
\hline & $\overline{M_{u} /{ }_{c} M_{u 2}}$ & 1.04 & 1.10 & 1.06 & 1.16 & 1.01 & 0.99 \\
\hline \multirow{5}{*}{$\begin{array}{l}\text { 崩罟温。 } \\
\left({ }^{\circ} \mathrm{C}\right)\end{array}$} & スラブ平均 & - & 98 & 116 & 520 & 172 & 175 \\
\hline & スタッド根元 & - & 293 & 378 & 377 & 475 & 355 \\
\hline & 上フランジ & - & 457 & 542 & 467 & 603 & 455 \\
\hline & ウェブ & - & 580 & 616 & 718 & 650 & 642 \\
\hline & 下フランジ & - & 541 & 606 & 730 & 651 & 635 \\
\hline \multirow{2}{*}{\multicolumn{2}{|c|}{$\begin{array}{l}\text { 崩壊時合成率 } \\
\text { (常温時合成率) }\end{array}$}} & 0.45 & 0.79 & 0.88 & 1.18 & 0.69 & 0.99 \\
\hline & & \multicolumn{4}{|c|}{$(0.45)$} & $(0.33)$ & $(0.96)$ \\
\hline
\end{tabular}

以上より, 本試験体のような不完全合成梁であっても, 火災時に おける合成梁の曲げ耐力は，評価モデル 1 および評価モデル 2 の応 力状態を仮定し, 各断面温度に応じた材料強度，スタッドのせん断 耐力を用いて評価できるものと考えられる。

\section{3 火災時におけるスラブの合成効果}

各試験体の加熱時の合成率と下フランジ温度の関係を図 22 に示 す。合成率は, 鉄骨梁の軸方向耐力 ${ }_{s} P_{y}$ とスラブの軸方向耐力 ${ }_{c} P_{y}$ の 最小值に対するスタッドの総せん断耐力 $\Sigma q$ の割合である。加熱時の ${ }_{s} P_{y},{ }_{c} P y$ および $\Sigma q$ と下フランジ温度の関係を図 23 に示す。いずれ の試験体も，昇温にともない ${ }_{s} P_{y}$ は低下しているのに対し， ${ }_{c} P$ と $\Sigma q$ の低下は僅かである。部材断面内に温度勾配があるために，鉄骨梁 の温度による強度低下に比べてスラブやスタッドの強度低下が小さ いためである。この結果, ${ }_{s} P_{y}$ よりも ${ }_{c} P$ 无大きい試験体では, 崩壊 時の合成率は常温時の合成率よりも大きくなっている。これは，火 災時の曲げ耐力にスラブの合成効果をより期待できることを意味す る。耐火被覆を施した $\mathrm{B}-2 / 3 \mathrm{rw}$ では, 図 10 に示すように, 下フラン ジとスタッド根元の温度差が大きいために, 崩壊時には $\Sigma q$ が ${ }_{s} P_{y}$ を 上回り, 合成率は 1 を超えて完全合成梁となっている。B-2/3sn は, 常温において ${ }_{s} P_{y}$ よりも ${ }_{c} P_{y}$ が小さい試験体である。昇温にともなう ${ }_{c} P_{y}$ と $\Sigma q$ の低下の程度がほぼ等しいため, 合成率はほとんど変化し ていない。崩壊時には ${ }_{s} P_{y}$ が $\Sigma q$ とほぼ等しい耐力まで低下したため 合成率は若干上昇している。

このように，鉄骨梁とスラブの軸方向耐力の大小関係の相違によ り，火災時の合成率は大きく異なる。すなわち，鉄骨梁の軸方向耐 力よりもスラブの軸方向耐力が大きい場合は，火災時におけるスラ ブの合成効果は常温時よりも増大するが，スラブの軸方向耐力の方 が小さい場合は火災時におけるスラブの合成効果の増加は小さい。

\section{5. まとめ}

本研究では, 単純支持された不完全合成梁の載荷加熱実験を行い, 合成梁が終局状態に至るまでの挙動および火災時におけるスラブの 合成効果を考慮した終局曲げ耐力を検討した。実験を行った範囲に 限定されるものの，本研究から得られた知見を以下に要約する。
1）鉄骨梁の伸び出し量は鉄骨梁の平均温度に比例して増加し, その 増加量は，鋼種，断面寸法，合成率に関わらず，鋼材の線膨張係 数 $\left(12 \times 10^{-6} /{ }^{\circ} \mathrm{C}\right)$ とほぼ同じであった。これより，スラブが鉄 骨梁の伸び出しを拘束する効果は小さいものと考えられる。

2) 鉄骨梁の伸び出し変形は, 崩壊温度に近づくとそれまでの伸びる 方向から縮む方向に反転し, 崩壊時には部材のたわみによる縮み 成分が卓越することが実験により確認された。

3）火災時の合成梁は部材断面内に温度勾配が生じるため, 鉄骨梁の 温度による強度低下に比べてスラブおよびスタッドの強度低下は 小さい。その結果，火災時の合成率は常温時の合成率よりも大き くなる。これは，火災時の曲げ耐力にスラブの合成効果をより期 待できることを意味する。ただし，鉄骨梁の軸方向耐力よりもス ラブの軸方向耐力が小さい場合には, 火災時における合成率の増 加は小さい。

4）塑性設計法に基づいた評価モデル 1 および評価モデル 2 の忍力状 態を仮定し, 部材の各断面温度に対応した鋼材とコンクリートの 材料強度およびスタッドのせん断耐力を用いて算定する合成梁の 火災時における終局曲げ耐力評価法を示した。本評価法は，合成 率を考慮しており，不完全合成梁に対しても適用できる。

大梁のように梁端部の回転が拘束された梁は，梁端部に生じる負 曲げモーメントによって単純支持梁よりも崩壊温度は高くなる ${ }^{10)}$ 。 一方で，合成梁の場合，負曲げ区間のスタッドが正曲げ耐力に寄与 するか，梁端部の負曲げ耐力を鉄骨梁の全塑性モーメントで評価で きるかなどを検討する必要がある。次報では，梁端部の回転を拘束 した合成梁の載荷加熱実験の結果と正曲げおよび負曲げ耐力の評価 法について報告する予定である。

\section{参考文献}

1）中川弘文, 鈴木弘之: 鋼梁の崩壊温度に関する実験, 日本建築学会構造工 学論文集, Vol.44B, pp.531 539, 1998.3

2）中川弘文, 鈴木弘之: 鋼梁の崩壊温度, 日本鋼構造協会鋼構造論文集, 第 6 巻, 第 22 号, pp. 57 65, 1999.6

3）窪田伸, 今野和近, 鈴木隆生, 高橋英孝, 平山博巳, 杉谷博 : FR 鋼の耐火 特性とこれを用いた合成梁の耐火性能, 日本建築学会大会学術講演梗概集 A-2, pp.43 46, 1999.9

4) 安田聡, 道越真太郎, 小林裕, 成原弘之: 高温における頭付きスタッドの せん断耐力に関する実験的研究, 日本建築学会構造系論文集, 第 73 巻, 第 630 号, pp.1417 1423, 2008.8

5）日本建築学会 : 各種合成構造設計指針・同解説， 1985.2

6）日本建築学会：鋼構造耐火設計指針・同解説，2008.3

7）西垣太郎, 杉田和直, 森本恭行 : 合成梁と鉄骨梁の載荷加熱実験, 日本建 築学会技術報告集，pp.67 70，第 7 号， 1999.2

8）日本建築学会：鋼構造限界状態設計指針・同解説，2002.9

9) Eurocode 4 : Design of composite steel and concrete structures, Part 1-1, General rules and rules for buildings, 2004

10）齋藤光 : 材端拘束鉄筋コンクリート部材の火災時の性状, 日本建築学会学 術講演梗概集，pp.761 762，1968.10

（2008年 7 月 10 日原稿受理， 2008年 9 月11日採用決定） 